\title{
Tying of aid reversed: alternative incentive schemes for development aid, productivity enhancement and change of income distribution
}

Citation for published version (APA):

Ziesemer, T. H. W. (1996). Tying of aid reversed: alternative incentive schemes for development aid, productivity enhancement and change of income distribution. MERIT, Maastricht Economic Research Institute on Innovation and Technology. MERIT Research Memoranda No. 001 https://doi.org/10.26481/umamer.1996001

Document status and date:

Published: 01/01/1996

DOI:

10.26481/umamer.1996001

Document Version:

Publisher's PDF, also known as Version of record

Please check the document version of this publication:

- A submitted manuscript is the version of the article upon submission and before peer-review. There can be important differences between the submitted version and the official published version of record.

People interested in the research are advised to contact the author for the final version of the publication, or visit the DOI to the publisher's website.

- The final author version and the galley proof are versions of the publication after peer review.

- The final published version features the final layout of the paper including the volume, issue and page numbers.

Link to publication

\footnotetext{
General rights rights.

- You may freely distribute the URL identifying the publication in the public portal. please follow below link for the End User Agreement:

www.umlib.nl/taverne-license

Take down policy

If you believe that this document breaches copyright please contact us at:

repository@maastrichtuniversity.nl

providing details and we will investigate your claim.
}

Copyright and moral rights for the publications made accessible in the public portal are retained by the authors and/or other copyright owners and it is a condition of accessing publications that users recognise and abide by the legal requirements associated with these

- Users may download and print one copy of any publication from the public portal for the purpose of private study or research.

- You may not further distribute the material or use it for any profit-making activity or commercial gain

If the publication is distributed under the terms of Article $25 \mathrm{fa}$ of the Dutch Copyright Act, indicated by the "Taverne" license above, 


\section{TYING OF AID REVERSED: ALTERNATIVE INCENTIVE SCHEMES FOR DEVELOPMENT AID, PRODUCTIVITY ENHANCEMENT AND CHANGE OF INCOME DISTRIBUTION*}

Thomas Ziesemer, Rijksuniversiteit Limburgl Maastricht, Department of Economics and MERIT.

\section{Introduction}

This paper deals with a normative issue of development aid, the grant element ${ }^{1}$ of official financial flows: Which way should it be paid? ${ }^{2}$

One current practice is to tie aid to spending (at special goods) in donor countries (Cashel-Cordo/Craig, 1990, section 2.1). Possible distributional paradoxes and inefficiencies of tying have been investigated in standard trade models under different assumptions about the manner of spending and financing by governments (Kemp/Kojima, 1985, 1986) and effectively constrained spending of the private sector (Schweinberger, 1990). The most straightforward way out in search of Pareto optimality is to finance aid lump sum $^{3}$, let it be spent un-tied and according to the preferences of the private sector.

However, there is a second strand of criticism of aid in the literature. The effectiveness ${ }^{4}$ of development aid has been severely criticized on three economic grounds. Firstly, its impact on the rate of growth is at best inconclusive in empirical investigations (Mosley/Hudson/Horrell, 1987). Secondly, poverty is still widespread and the effects of aid have been unable to outweigh other adverse circumstances (Cohen/Grindle/Walker, 1985), raising the question: has it been helpful at all? Thirdly, aid is seen to produce and reinforce dependence of the recipient (Griffin, 1970).

A Pareto efficient mode of paying aid does not, of course, guarantee poverty alleviation, although this may be the declared goal of donors. If no payment scheme can be found which makes

1 The intention in this paper is to isolate the aid question from the problems of the debt crisis, with which we shall deal elsewhere.

${ }^{2}$ For a broader discussion of development aid see the paper by Helmut Wagner in this volume and on the background of this paper Jepma (1991).

3 A payment is defined to be 'lump sum' if the amount paid does not depend on the behaviour of the recipient.

${ }^{4}$ The word 'efficiency' is used in the sense of Pareto optimality. 'Effectiveness' indicates the impact on the level or the growth rate of the GDP or GNP. 
this goal feasible in a Pareto efficient manner, a different incentive scheme becomes necessary, one which violates the Pareto efficiency requirement. Or, to put it differently, access to concessional resources may come at the price of having to follow the directives of donors (Cashel-Cordo/Craig, 1990, p.18). ${ }^{5}$

The purpose of this paper is to provide an example of an incentive scheme that alleviates poverty within the framework of a neoclassical growth model or increases the rate of growth within the framework of a Harrod-Domar growth model and to compare its effects on the three central variables outlined above, poverty alleviation, the growth process and dependency, with those of the lump sum paid aid which would follow the Pareto criterion.

The main results concerning lump sum paid aid are as follows. A lump-sum payment of aid, $\mathrm{X}$, with an exogenous growth rate $f$ (where $e$ is the exponential function and the time index)

$$
X=X_{0} e^{f t},
$$

which always increases the welfare of the recipient country according to the Pareto criterion, may lead to the following results:

a) Ineffectiveness in regard to long-run growth if the rate of growth of development aid is lower than the rate of growth of the closed economy model in a Harrod-Domar framework (section 2) as well as in the neoclassical growth model or in the latter if both growth rates are equal. However, a golden rule may lead to a recalculation of the rate of savings (section 4).

b) If the rate of growth of development aid is larger than the growth rate of the corresponding closed economy model dependence occurs (sections 2 and 4 ).

Therefore lump sum paid aid may be ineffective in regard to poverty alleviation, long run growth rates and dependence.

If, however, development aid is not paid lump sum but as a percentage $\mathrm{x}$ of the developing countries gross national product, $\mathrm{Y}, 6$

$$
\mathrm{X}=\mathrm{xY}
$$

the result is the following:

${ }^{5}$ See Wagner's paper on conditionality in this volume.

${ }^{6} \mathrm{x}$ may be different for each recipient country. For example a poor country may have a larger $x$ than a less poor country. As only one country is considered in the models below no country index is attached. In a slightly more complicate formulation, $x$ could be made dependent on the GNP of that country. This is not done here for the mere sake of simplicity. 
c) This income-dependent aid raises the rate of growth in the Harrod-Domar model (section 3) and the real wage rate of the neoclassical model even if a golden rule ${ }^{7}$ recalculation adjusts the savings rate (section 5 ).

This income-dependent incentive scheme produces an

excess burden on the recipient country but makes its wage earners better off, thus making them independent of the distribution of aid if compared to the case where aid is paid lump sum, provided this gain is not completely taken away through taxation. However, this can hardly be expected in the case of underdeveloped tax administrations actually observed, , where systems of income tax are not well developed or not stringently implemented. Such an assumption would of course render all approaches to alleviating the fate of the poor superfluous.

Hence, donors have the possibility to ensure that aid either increases growth in the recipient country, if the Harrod-Domar model comes close to reality, or, results in an improved income distribution if the neoclassical model adequately mirrors the growth process. A precondition for this is that donors shift from lump sum, Pareto efficient aid which may leave the lot of the poor unimproved, to an income-dependent, distribution- oriented incentive scheme which increases real wages. Thus an income-dependent incentive scheme may be superior either in regard to growth or poverty without leading to dependence, if the points of criticism mentioned above negatively enter the welfare function of donors. As both schemes analyzed in this paper are suggestions on reforming or revamping the current practice of tied aid, the task is initially purely theoretical, designed to trigger thinking about change.

\section{Lump sum aid in the Harrod-Domar model}

The production function - with $K$ as the capital input and a as a productivity parameter - is assumed to be

$$
\mathrm{Y}=\mathrm{aK}
$$

Savings $S$, out of income as well as development aid $\mathrm{X}$, finance investment.

If development aid grows at a constant rate $f$ according to (1) and savings are a constant share, s, of income $Y$ and aid X, these finance capital formation, $d K / d t, g^{2}$ en by ${ }^{8}$

$$
\dot{\mathrm{K}}=\mathrm{s}\left(\mathrm{aK}+\mathrm{X}_{0} \mathrm{e}^{\mathrm{ft}}\right)
$$

${ }^{7} \mathrm{~A}$ 'golden rule' indicates which behaviour allows for the highest long-run per-capita consumption.

${ }^{8} \mathrm{~A}$ dot on a variable indicates its time derivative. 
One of the properties of lump-sum payments is that aid depends no longer on certain project, but is at the free disposal of the country. ${ }^{9}$ The asymptotic result of the solution of this simple differential equation is ${ }^{10}$

$\lim _{t \rightarrow \infty} \hat{K}=\lim _{t \rightarrow \infty} \hat{Y}=\operatorname{Max}[s a, f]$

In the long run the impact of development aid on the rate of growth vanishes if the latter is smaller than the corresponding rate of the closed economy model sa. However, if sa $<$ the asymptotic rate of growth is completely donor determined, which may be called dependent development. Thus if the intention of the donor is to give aid until the receiving economy has matured, $f$ should be smaller than sa.

\section{Income-dependent aid in the Harrod-Domar model}

If development aid is paid according to (2) we obtain

$$
\dot{\mathrm{K}}=\mathrm{s}(1+\mathrm{x}) \mathrm{Y}=\mathrm{s}(1+\mathrm{x}) \mathrm{aK}
$$

instead of (4) and find the rate of growth

$$
\hat{K}=s(1+x) a
$$

If the rate of savings remains unchanged, income-dependent aid increases the rate of growth of $K$ and $Y$ in such a way that per capita incomes will grow faster. However, the question has always been whether or not the savings ratio and the capital productivity will remain unchanged (Griffin, 1970). Those who claim that the rate of savings will adjust implicitly use some framework of optimisation for the savings rate, the simplest of which is the golden rule in the descriptive neoclassical growth model. Therefore, we turn to this model now. However, if the rate of savings is unchanged, in a Harrod-Domar-model the rate of growth will be permanently higher under a scheme of income-dependent aid and therefore more effective in regard to variable.

${ }^{9}$ Recall that lump sum paid aid is a hypothetical alternative to what is done in reality. It is this alternative which is investigated here.

${ }^{10} \mathrm{~A}$ hat on a variable indicates a growth rate of that 
the rate of growth than lump sum aid, if $\mathrm{f}<\mathrm{s}(1+\mathrm{x}) \mathrm{a}$.

\section{Efficiency and effectiveness of lump-sum aid in the neoclassical growth model}

If investment is financed by savings and all aid is invested, then lump-sum aid according to (1) yields

$$
\dot{\mathrm{K}}=\mathrm{s}\left(\mathrm{Y}+\mathrm{X}_{0} \mathrm{e}^{\mathrm{ft}}\right)
$$

If output is produced in a linearly homogenous, neoclassical production function, $\mathrm{F}$, with labour input $\mathrm{L}$ and technology level A,

$$
Y=F(K, A L)
$$

the central differential equation of the standard growth model (for $A_{0} L_{0}=1$ ) becomes ( $\mathrm{n}$ is the growth rate of $\left.\mathrm{AL}\right)^{11}$

$$
\dot{\mathrm{k}}=\mathrm{s}\left[\mathrm{F}(\mathrm{k}, 1)+\mathrm{X}_{0} \mathrm{e}^{(\mathrm{f}-\mathrm{n}) \mathrm{t}}\right]-\mathrm{nk}
$$

For each given value of $\mathrm{k} \equiv \mathrm{K} / \mathrm{AL}$, a positive value of development aid $\left(\mathrm{X}_{0} \mathrm{e}^{(\mathrm{f}-\mathrm{n}) \mathrm{t}}>0\right)$ yields higher $\mathrm{dk} / \mathrm{dt}$ than the closed model and therefore arbitrary values of $\mathrm{k}$ will be reached faster. But in the long run we have

$\lim _{t \rightarrow \infty} x_{0} e^{(f-n) t}= \begin{cases}0 & \text { for } f<n \\ x_{0} & \text { for } f=n \\ \infty & \text { for } f>n\end{cases}$

If aid grows at a lower rate than the closed economy, $f<n$, the impact of aid on the change of the capital-labour ratio will vanish. If $f=n$ the economy arrives at a constant capital-labour ratio as in the closed model, but its level is higher than in the closed model. This can best be seen if aid is introduced into the standard graphical presentation of the model (see Figure 1); this case was already treated by Neher (1971, Chap.10) If $f>n$, the share of aid in financing investment approaches unity and the economy is dependent again. So the results for all three cases

${ }^{11}$ To obtain (6), divide both sides of (4' ') by $K$, subtract $\mathrm{n}$ from both sides, and multiply both sides by $\mathrm{k}$. 
of untied, lump-sum paid aid are very similar to those of the Harrod-Domar model.

A simple way to take account of an adjustment of the savings rate is to apply the golden rule to the case $\mathrm{f}=\mathrm{n}:{ }^{12}$

$\underset{\mathrm{k}}{\operatorname{Max}} \mathrm{C}=\mathrm{C} / \mathrm{L}=(\mathrm{Y}+\mathrm{X}-\mathrm{S}) / \mathrm{L}=\mathrm{AF}(\mathrm{k}, 1)-\mathrm{nkA}+\mathrm{X} / \mathrm{L}$

As $\mathrm{X}$ is independent of $\mathrm{k}$, the golden rule produces the same result as in the closed economy model: ${ }^{13}$

$$
\mathrm{F}_{1}\left(\mathrm{k}^{*}, 1\right)=\mathrm{n}
$$

The same $\mathrm{k}^{*}$ can only be reached at a lower steady state savings rate $s^{*}(s$. Figure 1$)$. Thus, recalculation of the optimal savings rate yields that aid is completely consumed, because savings per labour efficiency unit $\mathrm{S}(\mathrm{F}+\mathrm{X})$ is exactly as high as it was in the closed economy model, i.e. $\mathrm{nk}^{*}$, and therefore interest and wages are unchanged if compared to the closed model. So on the background of this model we expect a decrease in the rate of savings if aid is paid untied and lump sum. As this result is efficient from the standpoint of per capita consumption maximization, those who complain about it must have a different objective function.

The point of criticism that poverty has not been alleviated indicates that in the donor countries the well-being of the poor is an essential aspect of their individual welfare considerations. This can only be in contradiction to aggregate consumption maximization if that aid is distributed in such a way that the poor don't benefit (see Nitsch 1986 on this point). If the latter is expected by donors and the poor live on wage income, the question rises whether aid can be tied in such a manner as to raise wages. Clearly, such tying will be inefficient under the goal of aggregate consumption maximization but efficient under the goal of poverty alleviation in connection with the assumption that the poor have jobs and live on wages and won't benefit in case of lump sum aid. So donors may have to choose between the goals of aggregate consumption maximization and poverty alleviation. An incentive scheme that yields higher wages even if the receiving country behaves according to the golden rule is introduced in the next section.

${ }^{12} \mathrm{C}$ is the level of consumption and $\mathrm{C}$ is consumption per head.

${ }^{13} \mathrm{~A}$ lower index $i$ of $\mathrm{F}$ indicates a partial derivative with respect to the i-th argument of the function $F$. 

5. Distribution-oriented, income-dependent aid in the standard
neoclassical growth model.

If aid is paid according to (2) we find

$$
\dot{\mathrm{K}}=\mathrm{s}(1+\mathrm{x}) \mathrm{Y}
$$

and the central differential equation becomes

$$
\dot{\mathrm{k}}=(\hat{\mathrm{K}}-\mathrm{n}) \mathrm{k}=\mathrm{s}(1+\mathrm{x}) \mathrm{Y} / \mathrm{AL}-\mathrm{nk}=\mathrm{s}(1+\mathrm{x}) \mathrm{F}(\mathrm{k}, 1)-\mathrm{nk} \quad\left(6^{\prime}\right)
$$

A graph analogous to Figure 1 shows that there is no long-run impact on the rate of growth, but the steady state value of $\mathrm{k}$ is larger than in the closed model (see Figure 2). Now the essential question is whether or not the application of the golden rule will destroy this impact as under untied, lump sum aid. Now the golden rule problem is:

$\underset{\mathrm{k}}{\operatorname{Max}} \mathrm{C} / \mathrm{L} \equiv \mathrm{C}=(\mathrm{Y}+\mathrm{X}-\mathrm{S}) / \mathrm{L}=\mathrm{AF}(\mathrm{k}, 1)+\mathrm{xF}(\mathrm{k}, 1) \mathrm{A}-\mathrm{nkA}$

instead of (8) one finds (compare Figure 3)

$$
(1+x) F_{1}\left(k^{* *}, 1\right)=n
$$

The steady state of $\left(6^{\prime}\right)$ under a golden rule savings ratio $\mathrm{s}^{* *}$ is characterized by

$$
\mathrm{S}^{\star *}(1+\mathrm{x}) \mathrm{F}\left(\mathrm{k}^{\star *}, 1\right)=\mathrm{nk} \mathrm{k}^{\star *}
$$

where $\mathrm{k}^{* *}$ is determined through ( $\left.8^{\prime}\right)$ and the last equation determines $s^{* *}$ given $x$. In the model with untied, lump sum paid aid the optimal capital-labour ratio was determined by (8) and is denoted as $\mathrm{k}^{*}$ in Figure 3 . Its level is higher in this model of income-dependent aid because $F_{1}$ is lower; this is due to the fact that production is more profitable now, because each unit of output yields an additional unit of aid, which produces an incentive to employ more capital to increase output. This higher value of $\mathrm{k}^{* \star}$ has two important consequences: firstly, because of $\mathrm{w}=\mathrm{F}_{2} \mathrm{~A}$ the real wage, $\mathrm{w}$, is higher $\left(\mathrm{w}^{\star *}>\mathrm{w}^{*}\right)$; secondly, at the same level of aid in the two models the aggregate per capita consumption is lower, which can be shown as follows: at the same level of $X$ the level of per capita consumption in the two golden rule programs depends on $F(k, 1)$ - nk. This difference is maximized at $\mathrm{F}_{1}=\mathrm{n}$ and this is exactly the result of the golden 
rule under untied, lump-sum aid. In case of income-dependent aid it does not hold and therefore per capita consumption must be lower. The difference is a usual excess burden produced by the distortion $x$. If donors want to raise real wages because they cannot ensure that the poor benefit in case of untied, lump sum aid, tying of aid to output is a means of ensuring higher wage income. If profits are also raised, there will be no incentive for anyone to object to the payment of aid. Profits will be increased because $F_{1} k$ will be higher at $k^{* *}>k^{*}$ than at $k^{*}$ which can be seen as follows: ${ }^{14}$

$\mathrm{d}\left(\mathrm{F}_{1} \mathrm{k}\right) / \mathrm{dk}=\mathrm{F}_{1}+\mathrm{F}_{11} \mathrm{k} \underset{<}{ }=0$

implies

$$
\begin{aligned}
& > \\
& <-\mathrm{F}_{11} \mathrm{k} / \mathrm{F}_{1}
\end{aligned}
$$

multiplying both sides by $F / F_{2} A L \equiv y / F_{2}$ and making use of $-F_{11} \mathrm{k}=$ $\mathrm{F}_{21}$ yields

$$
\begin{aligned}
(\mathrm{F} / \mathrm{AL}) / \mathrm{F}_{2}=\mathrm{y} /(\mathrm{W} / \mathrm{A}) & \stackrel{>}{=} \mathrm{F}_{21} \mathrm{~F} / \mathrm{F}_{1} \mathrm{~F}_{2} \mathrm{AL} \equiv 1 / \sigma \\
& <
\end{aligned}
$$

The last term is the reciprocal of the elasticity of substitution $\sigma \equiv(\mathrm{dk} / \mathrm{d} \omega) \omega / \mathrm{k}$ where $\omega=\mathrm{w} / \mathrm{r}$. This condition can be rewritten as

$$
\begin{aligned}
\sigma & >\mathrm{WL} / \mathrm{Y} \\
& <
\end{aligned}
$$

If the elasticity of substitution is higher than the share of wages, profits will increase and therefore profit earners will have no incentive to oppose receiving aid. Clearly, they may prefer non-tied aid, but this is assumed here to be a decision of donors. If this condition is not fulfilled, the acceptance of aid may pose political problems. Unless there are other means of depriving wage earners of their increased income, which is rather unlikely under a very imperfect tax administration, our model shows that aid which is paid in proportion to the income of the receiving country will make them better off than if the aid is paid lump sum, i.e. at an independent growth rate. This implies that even with golden rule recalculation, the market mechanism - once it works as perfect as neoclassical economists believe it will after all liberalizations - ensures that wages

${ }^{14}$ If a lower index $i$ of function $F$ appears twice it indicates the second partial derivative with respect to the $i-t h$ argument of function $F$. 
will rise and poverty alleviated. Supposedly, in a model with unemployment, wages will rise less and employment will be increased. The result, that wage and profit income may be higher if compared to the lump sum payment of aid although there is an inefficiency is due to the fact that the incentive scheme produces an incentive for higher investment under a golden rule. Figure 3 graphically summarizes the comparison of steady states.

\section{Conclusion}

One current practice in development cooperation, that of tying aid to exports of goods and services from donors at the micro level, may be interpreted as a form even worse than lump sum payment of aggregate aid. If this practice were dropped and if instead an income-dependent aid scheme were introduced at the macro level, donors could achieve either an increase in the growth rate if the economy works as a Harrod-Domar model, or an increase in real wages if the economy works as a neoclassical model. In the latter case, the recipient economy would neither become entirely dependent nor would the impact of aid vanish due to recalculation of the savings ratio as in case of lump-sum aid. Possibly, future research will find even more effective variables than income upon which aid could be made dependent. ${ }^{15}$

\section{Bibliography}

Cashel-Cordo, P./Craig, S.G., 1990, 'The Public Sector Impact of International Resource Transfers', Journal of Development Economics $32,17-42$.

Cohen, J.M./Grindle, M.G./Walker, S.T., 1985, 'Foreign Aid and Conditions precedent: Political and Bureaucratic Dimensions', World Development, Vol.13, No.12, 1211-30.

Griffin, K., 1970, 'Foreign Capital, Domestic Savings and Economic Development', Oxford Bulletin of Economics and Statistics, 99-112.

Jepma, C. J., 1991, 'The Tying of Aid', OECD, Paris.

${ }^{15} \mathrm{E} . \mathrm{g}$. , the share of public investment in education as a share of GDP or the rate of taxation of individuals with higher incomes compared to that of the developed countries for individuals with the same income. In the latter case development aid would be paid only if individuals with about the same income in developing country actually pay the same taxes as people in donor countries do. 
Kemp, M.C./Kojima, S., 1985a, 'Tied Aid and the Paradoxes of Donor-Enrichment and Recipient-Impoverishment', International Economic Review, Vol.26, No.3, October, 1985.

1985b, 'The Welfare Economics of Foreign Aid', in Feiwel, G.R. ed., Issues in Contemporary Microeconomics and Welfare, London, Macmillan, 470-483.

Mosley, P./Hudson, J./Horrell, S., 1987, 'Aid, the Public Sector and the Market in Less Developed Countries', The Economic Journal, 97 (September), 616-64.

Neher, P.A., 1971, Economic Growth and Development, John Wiley, New York.

Nitsch, M., 1986, "Tödliche Hilfe"? Zur Modifikation der Außenwirtschafts- und Entwicklungstheorie durch die Einbeziehung des Verhaltens von Entwicklungsbürokratien', in:

ÖKONOMIE UND GESELLSCHAFT, Jahrbuch 4: Entwicklungsländer und Weltmarkt, Campus Verlag, Frankfurt/New York.

Schweinberger, A.G., 1990, 'On the Welfare Effects of Tied Aid', International Economic Review, Vol.31, No.2 (May), 457-62.

About the author: Thomas Ziesemer, born 17.12.53, has studied economics. He currently is Assistant Professor International Economics and Associate Professor Microeconomics, Rijksuniversiteit Limburgl Maastricht, the Netherlands. Fields of interest: Development economics, growth theory, international and environmental economics, economics of technical change and microeconomics.

*. I would like to thank U.K. Schittko for a helpful discussion, Gabriele Köhler and Utz-Peter Reich for many suggestions to make this paper more easily readable, the participants of the GAPE conference in Mainz 1995 for discussions on the topic and Corien Gijsbers and JoAnn van Rooijen-Cunneen, MERIT, for correcting shortcomings in my use of English language. Errors and views are entirely mine. 